DOI: 10.15393/j9.art.2013.376

Валентина Ивановна Габдуллина

доктор филологических наук, доиент, профессор кафедры титературы, Алтайская государственная педагогическая академия (Барнаул, Российская Федерация) vigv@mail.ru

\title{
МОТИВ ВОЗВРАЩЕНИЯ БЯУДНОГО СЫНА В РОМАНАХ И. С. ТУРГЕНЕВА
}

Аннотация: Автором уточняются представления о творчестве И. С. Тургенева как «нехристианского писателя», рассматривается проблема функционирования мотива блудного сына в цикле романов.

Тургеневым изображены различные фазы архетипического сюжета, восходящего к евангельской притче о блудном сыне. В романе «Рудин» автор изобразил фазу духовных блужданий героя, потерявшего связь с родным домом - Россией. В следующих романах («Дворянское гнездо», «Отцы и дети», «Дым»), проводя своего героя по кругу и возвращая его в родительский дом, Тургенев воспроизводит модель жизненного поведения человека, отраженную в притче, признавая тем самым непреложность идеи, зафиксированной в Евангелии.

Мотив возвращения на русскую почву получил свое завершение в последнем романе Тургенева «Новь», в котором автор парадоксальным образом соединяет западническую идею с евангельским императивом: Соломин - сын дьячка, отпущенный мудрым отцом «в обучение», учившийся в Англии, овладевший европейскими знаниями, вернулся «на родную почву» и основал свое дело в российской глубинке.

Таким образом, цикл романов Тургенева, в котором автор изобразил различные фазы общественной жизни, связан сквозным мотивом блудного сына, в роли которого выступает тургеневский герой.

Ключевые слова: евангельский мотив, архетип, блудный сын, роман Тургенева

B опрос о функционировании евангельских мотивов в поэтической системе романов И. С. Тургенева до сих пор не ставился в связи со сложившимся в литературоведении отношением к И. С. Тургеневу как к «нехристианскому» писателю, что представляется неправомерным, так как независимо от мировоззренческих установок писателя христианская образность входит в художественную ткань его произведений как отражение неотъемлемой черты русской жизни XIX века. 
Следует отметить, что взгляд на Тургенева как на бесспорного атеиста опровергнут в ряде современных исследований. Вопросы веры волновали Тургенева на протяжении всего его творчества, особенно в конце жизни. Сложный процесс самоидентификации писателя относительно христианской религии, который переживал Тургенев на протяжении всей жизни, рассматривает В. Н. Топоров в своей работе «Странный Тургенев». Исследователь указывает на автобиографический контекст, который обнаруживается в изображении духовных исканий тургеневского героя, в том числе и в вопросах веры. Строчки из юношеской поэмы Тургенева «Стено» («...я, / Как неба жажду веры ... жажду долго, / А сердце пусто до сих пор»), по мнению исследователя, - свидетельство мучительного осознания собственной неспособности постичь душу христианского вероучения, которое испытывал начинающий писатель. «Это отсутствие веры осознавалось как его личная ущербная особенность: что значит вера, об этом он догадывался, общаясь с людьми глубоко религиозными и черпавшими в вере жизненную силу. <..> Сам он дара веры был лишен или не сумел его развить» $[11,44]$.

Вместе с тем, пишет В. Н. Топоров, неуверенность в своей принадлежности к христианству не мешала писателю быть обладателем и носителем христианских представлений о нравственности: «Обладая высокими качествами души, которые можно считать христианскими по преимуществу, стремясь и в жизни своей быть (точнее - вести себя) христианином, Тургенев целомудренно никогда не называл себя христианином» $[11,45]$. Цитируя размышления писателя: «Имеющий веру, имеет все и ничего потерять не может, а кто ее не имеет, тот ничего не имеет... И если я не христианин, то это мое личное дело, мое личное несчастье...», - исследователь приходит к заключению: «Когда внутренний свет мерк и погасал, Тургенев тянулся к иному свету, от него ждал своего спасения, хотя и видел, что тяжелый мрак обступает со всех сторон этот слабый свет» $[11,45]$.

Мотив блудного сына актуализировался в творческом сознании писателя в связи с его собственным положением «русского европейца»', проводящего за границей большую 
часть жизни. Ф. М. Достоевский причислял И. С. Тургенева к типу русских людей, которых он назвал «русскими бездомными скитальцами». Намек на Тургенева содержится в высказывании Достоевского о русской интеллигенции, которая:

...от поколения к поколению, все менее и менее начинает понимать Россию <...> все более и более изменяет свой взгляд на нее, который у иных сузился, наконец, до размеров микроскопических, до размеров какого-нибудь Карлсруэ² $(27,15)^{3}$.

Нравственно-психологический комплекс «блудного сына», который обнаруживается в тексте биографии Тургенева (уход из дома, отрыв от России, скитания и духовный голод), коррелирует с основными структурными элементами сюжета притчи о блудном сыне. Тургенев принадлежал к поколению «русских европейцев», которые, оторвавшись от своих корней, не могли не испытывать чувства вины перед своим Домом. Конечно, нельзя утверждать, что вся жизнь писателя укладывается в архаическую схему. Скорее всего, биография Тургенева отразила общие для многих людей коллизии, связанные с семейными взаимоотношениями, с духовным самоопределением человека, получившие метафорическое воплощение в евангельской притче. Вместе с тем нельзя не заметить, что нравственные уроки евангельской притчи о блудном сыне, безусловно, хорошо известные Тургеневу как человеку XIX в., воспитанному на христианских текстах, нашли отражение в жизненных историях его героев, проходящих путь духовных исканий.

В литературоведении принято считать, что сюжеты произведений Тургенева разыгрываются «в трех планах: во-первых, это современно-бытовой, во-вторых, архетипический и, в-третьих, космический» [7, 728]. Архетипический план «раскрывает в новом старое или, вернее, вечное. Типы современности оказываются лишь актуализациями вечных характеров. <..>> Злободневное оказывается лишь кажимостью, а вечное сущностью. И если в первом случае сюжет развивается как отношение персонажей между собой, то во втором как отношение персонажей к их архетипам, текста - к тому, что стоит за ним», - пишет Ю. М. Лотман [7, 728]. 
Вопрос о функционировании архетипа блудного сына в сюжетах тургеневских романов в современном литературоведении является спорным. Так, например, по мнению А. В. Чернова: «Одинокий, и "нехристианский" герой Тургенева ("человек - точка между двумя вечностями") постоянно возвращается, но это возвращение особой природы. Тургеневский герой возвращается не к истоку, не к Отцу, а лишь к самому себе» $[12,156]$. Исследователь исходит из понимания Тургенева как «нехристианского» писателя, которому чужд религиозный взгляд на мир и человека. Мотив возвращения в романе Тургенева А. В. Чернов объясняет его философскими воззрениями: «Тургенев-художник глубоко чувствует неумолимый ритм возвращения, организующий человеческое бытие. Отсюда постоянные "кольцевые" композиции его повестей и романов» $[12,156]$.

В. Н. Захаров, предпринявший анализ романа Тургенева «Отцы и дети» в контексте православной модели мира, предлагает следующую трактовку эпилога романа: «В финале романа совершается торжество художественной правды: в парадигме поэтичного завершения сюжета автор одолевает свои предубеждения, смиряется перед таинственной жизнью природы, народа, России» $[4,37]$.

В шести романах Тургенева изображены различные фазы архетипического сюжета. В романе «Рудин» автор изобразил фазу духовных блужданий героя, потерявшего связь с родным домом - Россией («Несчастье Рудина состоит в том, что он России не знает, и это, точно, большое несчастье», - говорит о нем Лежнев). Путь домой героем так и не найден - он умирает на чужой земле. В этом суть трагедии поколения «лишних людей» - «блудных детей» России, изображенной Тургеневым.

В следующих романах («Дворянское гнездо», «Отцы и дети», «Дым»4), проводя своего героя по кругу и возвращая его в родительский дом, Тургенев воспроизводит модель жизненного поведения человека, отраженную в притче о блудном сыне, признавая тем самым непреложность идеи, зафиксированной в Евангелии - «неизбежность возвращения к истоку, к Богу-Отцу, через падение, искупление, право 
быть тем, чем должен быть человек изначально как творение и подобие Божие» $[12,152]$.

Остановимся подробнее на изображении фазы возвращения «блудного сына» в романе И. С. Тургенева «Дым» тором писатель обращается к теме «русских иностранцев».

Появление в печати романа «Дым» (1867) было встречено бурной полемикой, обращенной в основном против шаржированного изображения в романе русской политической эмиграции и западнических идеалов автора ${ }^{6}$.

Как признавал сам Тургенев в предисловии ко второму изданию «Дыма», больше всего споров вызвала мысль, положенная в основание характера Потугина - «лица, по-видимому, более всех других оскорбившего патриотическое чувство публики» (VII, 408)7. Объектом сатиры автора «Дыма» стали "русские европейцы», утратившие связи с Россией. Западнику Потугину Тургенев противопоставил в романе тип современного прогрессивно мыслящего русского помещика, в образе которого отразилась положительная сторона его программы. Григорий Литвинов замыкает собой галерею героев-практиков, которые приходят к пониманию необходимости «дело делать». Рассматривая образ Литвинова в связи с вопросом о центральном герое романа «Дым» в контексте полемики по поводу героя-деятеля у Тургенева, А. Б. Муратов замечает: «Центральный герой "Дыма" Литвинов, в связи с этим и стал для Тургенева таким полезным деятелем не в широком, историческом, а в более узком и скромном, практическом смысле этого понятия» [8, 41]. Как пишет П. Г. Пустовойт, «Тургенев считал, что нынешний герой дня - это скромный труженик, маленький и незаметный, "дюжинный честный человек", каким он представлял Литвинова. Однако Литвинов получился не столько скромным тружеником, сколько хозяином, лишь стремящимся к преобразовательской деятельности; по существу - это Лежнев из романа "Рудин", только оказавшийся в иных условиях» [10, 197]. Предшественниками Литвинова были, наряду с Лежневым, и Федор Лаврецкий, и Аркадий Кирсанов, каждый из которых прошел свой путь «блудного сына», прежде чем обратился к труду на «отцовской ниве». 
В истории Григория Михайловича Литвинова архетипический мотив блудного сына, как всегда у Тургенева, претерпевает определенную трансформацию и заявлен в тексте посредством системы аллюзий. Актантно-предикативная система притчи (отец, сын - уход, испытания, возвращение) прочитывается как на сюжетном, так и на символическом уровнях текста романа.

В предыстории героя - жизнь в России, попытки вести хозяйство в имении матери вместе с «одряхлевшим отцом». Отъезд Григория Литвинова из дома за границу мотивирован необходимостью приобретения знаний:

Он понимал, что имение его матери, плохо и вяло управляемое его одряхлевшим отцом, не давало и десятой доли тех доходов, которые могло бы давать, и что в опытных и знающих руках оно превратилось бы в золотое дно; но он также понимал, что именно опыта и знаний ему недоставало, - и он отправился за границу учиться агрономии и технологии, учиться с азбуки (VII, 254).

Таким образом, в романе «Дым» мы имеем дело с тем вариантом интерпретации сюжета притчи о блудном сыне, который был популярен в повестях петровского времени, что согласуется с западническими взглядами Тургенева. Автор «Дыма» остается верен идеям, оформившимся еще в период написания его первого очерка из цикла «Записки охотника», в котором Тургенев называет Петра Великого по преимуществу русским человеком, русским именно в своих преобразованиях, на том основании, что этот великий русский реформатор проявил, по мнению писателя, капитальную черту русского человека, обнаруженную автором и у крестьянина Хоря:

Русский человек так уверен в своей силе и крепости, что он не прочь и поломать себя. <...> Что хорошо - то ему и нравится, что разумно - того ему и подавай, а откуда оно идет, - ему все равно. Его здравый смысл охотно подтрунит над сухопарым немецким рассудком; но немцы, по словам Хоря, любопытный народец, и поучиться у них он готов (III, 16).

Путь приобщения к плодам западной цивилизации для русского человека и для России оценивается Тургеневым как 
исторически необходимый. Для Литвинова учеба за границей (в Мекленбурге, в Силезии, в Карлсруэ, в Бельгии и в Англии) стала тем необходимым «искусом» ${ }^{8}$, который должен был подготовить его к деятельности на благо России. Литвинов

...трудился добросовестно, приобрел познания: нелегко они ему давались; но он выдержал искус до конца, и вот теперь, уверенный в самом себе, в своей будущности, в пользе, которую он принесет своим землякам, пожалуй, даже всему краю, он собирается возвратиться на родину (VII, 254).

Все эти планы Литвинова рухнули в одночасье, когда в его жизнь ворвалось страстное чувство к Ирине:

...им овладел ужас при мысли, что будущность, его почти завоеванная будущность, опять заволоклась мраком, что его дом, его прочный, только что возведенный дом внезапно пошатнулся... (VII, 342).

Понятие дом, в данном случае, трактуется Тургеневым в духе христианских представлений о доме-дуще - нарушенный душевный покой, который герой связывал с планами возвращения на родину, под родной кров, созданием семейного очага с любимой женщиной, которую он называет «ангелом-хранителем», ассоциируется в его сознании с пошатнувшимся домом. С этого момента в повествовании романа начинает разворачиваться мотив бесовского наваждения, искушения плоти и духа, через которые проходит герой, прежде чем вновь вернуться в свой Дом.

Весь облик искусительницы Ирины дан в инфернальных тонах:

...образ Ирины так и воздвигался перед ним в своей черной, как бы траурной одежде. <...> Испорчена до мозга костей <..> но горда как бес, у Литвинова защемило на сердце, холодно ему стало, физически холодно: мгновенная дрожь пробежала по телу, слабо стукнули зубы (VII, 342).

Контрастен портрету Ирины облик Татьяны, которую Литвинов называет «мой ангел, мой добрый гений»: 
...с удивительным выражением кротости в умных, светло-карих глазах, с нежным белым лбом, на котором, казалось, постоянно лежал луч солнца (VII, 341).

Объяснение Литвинова с Ириной сопровождается мистической деталью: «...залетевшая бабочка трепетала крыльями и билась между занавесом и окном», «бабочка по-прежнему билась и трепетала» (VII, 344), символизирующей трепещущую и бьющуюся между светом (светлой, гармоничной любовью к Татьяне) и мраком (страстью к Ирине) душу героя 9 .

Когда Литвинов впустил в свою душу любовь-страсть, он почувствовал, что

...таинственный гость забрался в святилище и овладел им, и улегся в нем, молчком, но во всю ширину, как хозяин на новоселье (VII, 352).

Перипетии взаимоотношений Литвинова с Ириной сопровождаются комментариями автора, передающими ощущения, которые испытывает герой, погружающийся в темную бездну, сродни преисподней:

Он чувствовал одно: пал удар, и жизнь перерублена, как канат, и весь он увлечен вперед и подхвачен чем-то неведомым и холодным. Иногда ему казалось, что вихорь налетел на него, и он ощущал быстрое вращение и беспорядочные удары его темных крыл... (VII, 347); Появилось какое-то небывалое ощущение, сильное, сладкое - и недоброе (VII, 352); Темная бездна внезапно обступила его со всех сторон, и он глядел в эту темноту бессмысленно и отчаянно (VII, 391).

Философия любви у Тургенева включает в себя романтические представления о любви как высшей сфере духовной жизни человека. Вместе с тем трудно согласиться с Г. Б. Курляндской, которая считает, что Тургенев «принял идеал единства естественного и нравственного в любви, чувственного и духовного в ней, но при этом освободил любовь от так называемой трансцендентной сущности» [6, 32]. Любовь для Тургенева и его героев - всегда нечто непостижимое, неподвластное разумному объяснению, несущее как жизнь, так и смерть. «О взаимной связи любви и смерти в самом их едином корне и, следовательно, об их родстве, и более того близ- 
нечестве Тургенев, конечно, знал, как знали об этом и поведали миру Тютчев и Бодлер», - замечает В. Н. Топоров [11, 54], говоря о мистической концепции любви у Тургенева. В романе «Дым» наблюдается усиление «мистического элемента», обусловленного мировоззренческим кризисом писателя, что проявилось и в его трактовке любви. В романе представлены два типа любви, которые сталкиваются в душе героя, почти в духе Достоевского - «черт с Богом борются».

Еще в повести «Переписка» (1856 г.) Тургенев устами своего героя так определяет любовь:

Любовь даже вовсе не чувство; она болезнь, известное состояние души и тела; она не развивается постепенно; в ней нельзя сомневаться, с ней нельзя хитрить, хотя она и проявляется не всегда одинаково; обыкновенно она овладевает человеком без спроса, внезапно, против его воли - ни дать ни взять холера или лихорадка... (V, 47).

Герой «Переписки» проходит путь, уготованный автором и Литвинову; Алексей Петрович исповедуется в одном из писем к Марье Александровне:

В первой молодости я непременно хотел завоевать небо... потом я пустился мечтать о благе всего человечества, о благе родины; потом и это прошло: я думал только, как бы устроить себе домашнюю, семейную жизнь... да споткнулся о муравейник - и бух оземь, да в могилу... (V, 47).

Нечто подобное происходит и с Литвиновым, с той разницей, что ему удалось вернуться из бездны.

Любовь к Ирине и измена своему ангелу-хранителю Татьяне переживается Литвиновым как болезнь «по медицинской части недоступная», подобная той, о которой он узнал накануне из письма отца, писавшего, что его

...дворовый человек Никанор Дмитриев был одержим болезнию, по медицинской части недоступною... а причиной он сам, Никанор, ибо свое обещание перед некой девицей не исполнил... $(\mathrm{VII}, 278)^{10}$.

Только после возвращения в свое поместье Литвинов постепенно возвращается к жизни: 
И дух в нем окреп: он снова стал походить на прежнего Литвинова; исчезло мертвенное равнодушие, и среди живых он снова двигался и действовал, как живой (VII, 401).

Окончательное воскресение ${ }^{11}$ Григория Литвинова происходит только после его покаяния. «Повинную голову принес», - говорит о нем Капитолина Марковна, когда Литвинов,

...упав перед Татьяной на колени, лобызал край ее одежды (VII, 405).

В финале вновь появляется образ дома - теперь это новенький домик, где жила его бывшая невеста Татьяна, который «стоял на холме, над небольшой речкой, посреди недавно разведенного сада», как символ новой жизни, которая начинается для Литвинова после его воскресения из мертвых.

«Возвращается к себе прежнему Литвинов, и это возвращение героя к нормальному, естественному человеческому бытию, отрицание затмевающего смысл и цель жизни «дыма» приводит к закономерному итогу», - пишет А. В. Чернов, замечая, что «в «Дыме» Тургенев наиболее близок к первому направлению, к роману «гончаровского» типа - это единственный роман Тургенева со «счастливым» финалом» $[12,156]$.

Следует заметить, что возвращцение героя в романе «Дым» в деталях отличается от финалов «Дворянского гнезда» и «Отцов и детей», в которых возвращение изображено, по выражению А. В. Чернова, «в снятом виде». В «Дыме» представлен новый вариант трансформации притчевой схемы «блудного сына» в романе Тургенева воскрешает к жизни любовь и прощение женщины. Актантно-предикативные отношения в финале романа модифицированы: место отца замещают две женщины - тетушка Капитолина Марковна и Татьяна. Обе они ведут себя подобно Отцу из притчи, встречая раскаявшегося Литвинова: он издали видит на балконе женщину в белом, ожидающую его, Капитолина Марковна встречает Литвинова на крыльце (подобно отцу Евгения Базарова) вне себя от радости.

Поза Литвинова, стоящего на коленях перед Татьяной, воспринимается как покаянная, отсылающая к традиционным изображениям финального эпизода притчи о блудном сыне. Неслучаен выбор имени героини: имя Татьяна прочи- 
тывалось современниками Тургенева в пушкинском контексте $^{12}$ как знак русской душою героини, именно она призвана возродить Литвинова к новой жизни. Возвращение Литвинова к своей невесте Татьяне в финале романа - означает окончание его духовных скитаний, возвращение Домой.

Мотив возвращения на русскую почву получил свое завершение в последнем романе Тургенева «Новь». «Отыска-

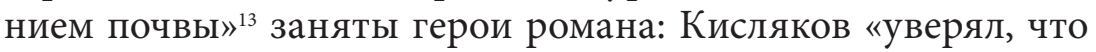
он первый отыскал, наконец "почву"» (IX, 228).

Нежданов «упомянул даже об отыскании почвы» (IX, 253). В конце подготовительных материалов к роману появляется запись: «почва!» (IX, 422). Однако по-настоящему вернулся на русскую почву только Соломин - сын дьячка, отпущенный мудрым отцом «в обучение», учившийся в Англии, овладевший европейскими знаниями и основавший свое дело в российской глубинке - «где-то там, в Перми, на каких-то артельных началах» (IX, 384).

Таким образом, цикл романов Тургенева, в котором автор изобразил различные фазы общественной жизни, связан сквозным мотивом блудного сына, в роли которого выступает тургеневский герой.

\section{Примечания}

1 О феномене "русского европейца» в русской культуре и в жизненной практике поколения русских людей, к которому принадлежал И. С. Тургенев, см.: $[5,200]$.

2 Карлсруэ - небольшой европейский городок, на сцене оперного театра которого выступала Полина Виардо, - одно из мест пребывания И. С. Тургенева за границей; в Карлсруэ учился вести хозяйство в русском поместье герой «Дыма» Литвинов.

3 Цит. по: Достоевский Ф. М. Полн. собр. соч.: В 30 т. Л.: Наука, 1984. T. 27. 463 с. Номер тома и страницы указан в круглых скобках.

4 Роман «Накануне», также содержащий мотив блудного сына, в данной статье не рассматривается, так как, на взгляд автора, требует специального исследования.

5 О функционировании мотива блудного сына в романах «Дворянское гнездо» и «Отцы и дети» см.: [1, 253-260]; [2, 140-148].

6 См. об этом: $[8,124-144]$. 
7 Цитаты приводятся по: Тургенев И. С. Полн. собр. соч. и писем: В 30 т. Сочинения: В 12 т. М.: Художественная литература, 1981-1986. Номер тома и страницы указывается в круглых скобках после цитаты.

8 Слово искус употребляется в данном случае Тургеневым в значении испытание, опьы , проба. См. о семантике слова искус: Даль В. Толковый словарь живого великорусского языка: В 4 т. М.: Русский язык, 1979. Т. 2. С. 52. В. Даль приводит пословицу: Искусом до всего дойдешь.

9 Бабочка в христианском искусстве является символом человеческой души. См.: Холл Дж. Словарь сюжетов и символов в искусстве. М.: КРОНН-ПРЕСС, 1996. 656 с. 89.

10 Письмо с историей Никанора Дмитриева, которое повеяло на Литвинова «степной глушью, слепым мраком заплесневшей жизни», неслучайно введено в текст романа и выполняет профетическую функцию, предсказывая самому Литвинову наказание за то, что он тоже «свое обещание перед некой девицей не исполнил». То, что казалось ему суеверием, оказалось проявлением одной из загадок любви.

11 Состояние Литвинова, когда он получил письмо от Татьяны с приглашением посетить ее с Капитолиной Марковной сравнивается автором с воскресающей поутру землею: «И легко ему стало вдруг и светло... Так точно, когда солнце встает и разгоняет темноту ночи» (VII, 401).

12 Об инверсиях сюжетных ситуаций романа Пушкина «Евгений Онегин» в произведениях Тургенева см.: [3, 32-43]; [9, 130-137].

13 Понятие почва широко использовалось в публицистике 18601880 -х гг., но, прежде всего, оно связывалось с идеологической концепцией «почвенничества», сформулированной Ф. М. Достоевским в его журнале «Время». Тургенев, диалогически настроенный по отношению к Достоевскому, вводя это понятие в свой роман, продолжает идеологический спор с Достоевским по поводу перспектив развития России.

\section{Список литературы}

1. Габдуллина В. И. Мотив блудного сына в романе И. С. Тургенева «Отцы и дети» // Культура и текст: миф и мифопоэтика. СПб.; Самара; Барнаул: Изд-во БГПУ, 2004. С. 253-260.

2. Габдуллина В. И. Трансформация мотива блудного сына в романе И. С. Тургенева «Дворянское гнездо» // Культура и текст - 2005. СПб.; Самара; Барнаул: БГПУ, 2005. Т. I. С. 140-148. 
3. Гольцер С. В. Роман И. С. Тургенева «Дым» в свете онегинской традиции // Молодая филология: Сб. научных трудов. Новосибирск, 2001. Вып. 3. С. 32-43.

4. Захаров В. Н. «Вечное Евангелие» в художественных хронотопах русской словесности // Проблемы исторической поэтики. Петрозаводск; СПб.: Алетейя, 2011. Вып. 9: Евангельский текст в русской литературе XVIII-XX веков: цитата, реминисценция, мотив, сюжет, жанр. Вып. 6. С. 24-37.

5. Кантор В. К. Русский европеец как явление культуры (философско-исторический анализ). М.: Наука, 2001. 704 с.

6. Курляндская Г. Б. Художественный метод Тургенева-романиста. Тула: Приокское книжное изд-во, 1972.344 с.

7. Лотман Ю. М. Сюжетное пространство русского романа XIX столетия // Лотман Ю. М. О русской литературе. СПб.: Искусство-СПБ, 1997. C. 712-729.

8. Муратов А. Б. Тургенев после «Отцов и детей». Л.: Наука, 1972. 144 с.

9. Печерская Т. И. «Ужель та самая Татьяна»? (Инверсии пушкинского сюжета в романе Тургенева «Отцы и дети») // Материал к Словарю сюжетов и мотивов русской литературы. Вып. 5: Сюжеты и мотивы русской литературы. Новосибирск: Изд-во НГУ, 2002. С. 130-137.

10. Пустовойт П. Г. И. С. Тургенев - художник слова. М.: Изд-во МГУ, 1987. $379 \mathrm{c}$.

11. Топоров В. Н. Странный Тургенев. М.: Изд-во РГГУ, 1998. 192 с.

12. Чернов А. В. Архетип «блудного сына» в русской литературе XIX века // Проблемы исторической поэтики. Петрозаводск: ПетрГУ, 1994. Вып. 3: Евангельский текст в русской литературе XVIII-XX веков: цитата, реминисценция, мотив, сюжет, жанр. Вып. 1. С. 151-158.

\section{Valentina Ivanovna Gabdullina}

Ph.D. in Philology,

Professor of the Department of Literature, Altaian State Pedagogical Academy (Barnaul, Russian Federation) vigv@mail.ru

\section{THE MOTIF OF THE PRODIGAL SON IN IVAN TURGENEV'S NOVELS}

Abstract: The author questions the perception of Ivan Turgenev as a "nonChristian writer" and studies the problem of the prodigal son motif functioning in a series of his novels.

In his novels, Turgenev pictured different phases of the archetypal story, originating from the Gospel parable of the prodigal son. In the novel Rudin he depicted the phase of spiritual wanderings of the hero who had lost touch with his native land - Russia. In his next novels (Home of the Gentry, Fathers and Sons and Smoke), after leading his hero in circles and sending him back 
to his paternal home, Turgenev reconstructs the model of human behavior, represented in the parable, thereby recognizing the immutability of the idea formalized in the Gospel.

The motif of the return to Russian land gets its completion in Turgenev's last novel Virgin Soil, in which the author paradoxically connects the Westernist idea with the Gospel imperative. Solomin, the son of a deacon, sent by his wise father out to Europe "to get education", studies in England, masters the European knowledge and returns back "to his native land" to establish his own business in inland Russia.

Thus, a series of Turgenev's novels, in which he portrayed different phases of social life, are interlinked with the motif of the prodigal son, who is represented by novels' main characters.

Keywords: Gospel motif, archetype, the prodigal son, Ivan Turgenev's novels

\section{References}

1. Gabdullina V. I. Motiv bludnogo syna v romane I. S. Turgeneva «Ottsy i deti» [The Motif of the Prodigal Son in Ivan Turgenev's novel "Fathers and Sons"]. Kul'tura i tekst: mif i mifopoetika [Culture and Text: Myth and Mythopoetics]. Saint-Petersburg; Samara; Barnaul, Barnaul State Pedagogical University Publ., 2004, pp. 253-260.

2. Gabdullina V. I. Transformatsiya motiva bludnogo syna v romane I. S. Turgeneva «Dvoryanskoe gnezdo» [The Transformation of the Motif of the Prodigal Son in Ivan Turgenev's novel «Home of the Gentry»]. Kul'tura $i$ tekst - 2005 [Culture and Text - 2005]. Saint-Petersburg; Samara; Barnaul, Barnaul State Pedagogical University Publ., 2005, vol. 1, pp. 140-148.

3. Gol'tser S. V. Roman I. S. Turgeneva «Dym» v svete oneginskoy traditsii [Ivan Turgenev's Novel "Smoke" in the Light of the Onegin's Tradition]. Molodaya filologiya [Young Philology]. Novosibirsk, 2001, issue 3, pp. 32-43.

4. Zakharov V. N. «Vechnoe Evangelie» v khudozhestvennykh khronotopakh russkoy slovesnosti [The «Everlasting gospel» in the artistic hronotop of the Russian literature]. Problemy istoricheskoy poetiki [The Problems of Historical Poetics]. Petrozavodsk; St. Petersburg: Aleteyya Publ., 2011. Vol. 9: Evangel'skiy tekst $v$ russkoy literature XVIII-XX vekov: tsitata, reministsentsiya, motiv, syuzhet, zhanr [The Gospel Text in Russian Literature of the 18th-20th Centuries: Quotation, Reminiscence, Motif, Plot, Genre]. Issue 6, pp. 24-37.

5. Kantor V. K. Russkiy evropeets kak yavlenie kul'tury (filosofskoistoricheskiy analiz) [Russian European as a Cultural Phenomenon (Philosophical and Historical Analysis)]. Moscow, Nauka Publ., 2001. $704 \mathrm{p}$.

6. Kurlyandskaya G. B. Khudozhestvennyy metod Turgeneva-romanista [Literary Method of the Novelist Turgenev]. Tula, Priokskoe knizhnoe Publ., 1972. 344 p.

7. Lotman Yu. M. Syuzhetnoe prostranstvo russkogo romana XIX stoletiya [Narrative Space of the 19th Century Russian Novel]. Lotman Yu. M. O 
russkoy literature [Lotman Yu. M. About Russian Literature]. SaintPetersburg, Iskusstvo-SPb Publ., 1997, pp. 712-729.

8. Muratov A. B. Turgenev posle "Ottsov i detey» [Ivan Turgenev after «Fathers and Sons»]. Leningrad, Nauka Publ., 1972. 144 p.

9. Pecherskaya T. I. «Uzhel' ta samaya Tat'yana»? (Inversii pushkinskogo syuzheta v romane Turgeneva "Ottsy i deti») ["Could it be that the same Tatiana»? (Inversions of Pushkin's Plot in Turgenev's Novel «Fathers and Sons»)]. Material k Slovaryu syuzhetov i motivov russkoy literatury [Materials for the Dictionary of Plots and Motifs of Russian Literature]. Issue 5. Novosibirsk, Novosibirsk State University Publ., 2002, pp. 130-137.

10. Pustovoyt P. G. I. S. Turgenev - khudozhnik slova [I. S. Turgenev, the Artist of the Word]. Moscow, Moscow State University Publ., 1987. 379 p.

11. Toporov V. N. Strannyy Turgenev [Strange Turgenev]. Moscow, Russian State University for the Humanities Publ., 1998. 192 p.

12. Chernov A. V. Arkhetip «bludnogo syna» v russkoy literature XIX veka [The Archetype of the Prodigal Son in Russian Literature of the 19th Century]. Problemy istoricheskoy poetiki [The Problems of Historical Poetics]. Petrozavodsk, Petrozavodsk State University Publ., 1994. Vol. 3: Evangel'skiy tekst $v$ russkoy literature XVIII-XX vekov: tsitata, reministsentsiya, motiv, syuzhet, zhanr [The Gospel Text in Russian Literature of the 18th-20th Centuries: Quotation, Reminiscence, Motif, Plot, Genre]. Issue 1, pp. 151-158. 